\title{
The graduation performance of technology business incubators in China's three tier cities: the role of incubator funding, technical support, and entrepreneurial mentoring
}

\author{
Li Xiao ${ }^{1} \cdot$ David North ${ }^{2}$
}

Published online: 31 August 2016

(C) The Author(s) 2016. This article is published with open access at Springerlink.com

\begin{abstract}
This study examines the effects of technology business incubator (TBI)'s funding, technical support and entrepreneurial mentoring on the graduation performance of new technology-based firms in China's three tier cities. Using a new dataset on all TBIs and incubated new technology-based firms from government surveys conducted over five consecutive years from 2009 to 2013 combined with archival and handcollected data, we find the effects of incubator services on the early growth of new technology-based firms vary according to the local context. Technical support facilities and entrepreneurial mentoring from TBIs are found to have significantly and positively influenced the early development of the firms in the four most affluent tier 1 cities, whilst these effects become less pronounced for the tier 2 and tier 3 cities. These two services are also found to influence graduation performance in the government and university types of TBI respectively. Results support the notion that the effectiveness of an incubator's services is shaped by the level of a city's socio-economic development and that the city location of a TBI does impact the graduation performance of its incubatees.
\end{abstract}

Keywords Graduation performance - TBIs · New technology-based firms - Incubator research facilities, funding and mentoring - China

JEL Classification $\mathrm{O} 3$

Li Xiao

1.xiao@lancaster.ac.uk

David North

d.north@mdx.ac.uk

1 Department of Entrepreneurship Strategy and Innovation, Lancaster University Management School, Lancaster LA1 4YX, UK

2 Centre for Enterprise and Economic Development Research, Middlesex University, The Burroughs, London NW4 4BT, UK 


\section{Introduction}

The principal drivers for establishing technology business incubators (TBIs) are to facilitate the formation and growth of early stage technology-based firms and to promote regional economic development by providing much needed support services (Phan et al. 2005; Ratinbo and Henriques 2010; Markman et al. 2005; McAdam and McAdam 2008; Siegel et al. 2007, 2003). State authorities in a diverse range of both developed and developing economies have invested public resources and encouraged private investment in establishing TBIs to address the market failures associated with the early stages of firm development (OECD 1997; Phan et al. 2005) and/or to accelerate the entrepreneurial process through institutionalising the support for ventures with high growth potential (Hansen et al. 2000). The main focus of TBIs is on helping to raise early stage technologybased ventures up to a level where they can seize business opportunities and compete in the market without further support (Rothaermel and Thursby 2005a; Bollingtoft and Ulhoi 2005; Schwartz 2012). As such, the effectiveness of a TBI is often gauged by the graduation performance of the incubated ventures, as measured by the number of viable early stage firms that leave an incubator over a specified period of time (Phan et al. 2005; Aernoudt 2004).

One of the central features of TBIs is the provision of various resources that are essential to new technology-based ventures, but not available internally and/or externally (Aerts et al. 2007; Bruneel et al. 2012). They are usually allocated to individual resident firms to compensate for limited access to key resources from the local economy or to facilitate access to a shared research and technical infrastructure for lowering the research/operation costs of firms (Storey and Tether 1998; Aerts et al. 2007; Bruneel et al. 2012), thereby reducing the 'liability of newness' (Ferguson and Olofsson 2004). Increasingly in western countries, TBIs are acting as mediators between entrepreneurs and providers of key resources (e.g. business angels, venture capitalists, academic scientists, experienced entrepreneurs). Although scholars agree on the critical role that incubators in the USA, UK, and other European countries play in building networks that can be transformative to the development of their incubatees (Mian 1996; Hansen et al. 2000; Colombo and Delmastro 2002; Bollingtoft and Ulhoi 2005; Sa and Lee 2012), it is not evident that these factors have been so important in Asian countries (Chan and Lau 2005). Literature on incubators in these countries indicates that support associated with cost reductions (e.g. free or subsidised rental and testing facilities) is far more important than the provision of network opportunities to early stage technology-based ventures since technological entrepreneurs are likely to rely on their own networks with scientists (Chan and Lau 2005; Zhang and Sonobe 2011). There is therefore a need, particularly in Asian countries, for further investigation on which specific support services provided by TBIs accelerate the early growth of new technology-based ventures and contribute to their graduation (Phan et al. 2005). Moreover, it has been noted that the influence of different geographic contexts on TBIs has been an under-explored research area, requiring survey data covering multiple regions (McAdam et al. 2016).

This paper examines whether the three most established support services provided by TBIs in China influence the graduation performance of their resident firms over a 5 year period as well as addressing the relatively neglected aspect of comparing TBIs within different geographical contexts. TBIs in China help technological entrepreneurs create, scale up, and grow new technology-based ventures by offering a wide range of support services. The support infrastructure evolves over time and includes low cost office space, 
business registration and patenting services, networking with other government services, facilities for R\&D and innovation and financial capital. The quality and scale of each type of support are associated with a TBI's ownership, operational model, objectives, and geographic context as well as beiing driven by public resource allocation at different government levels. Given the rapid growth of TBIs in China over the last decade, it presents a fascinating context in which to study the influences of both TBI services and other external factors on the early development of new technology-based enterprises.

The effects of TBIs on the graduation performance of incubatees may also vary according to the economic and social development of a city where a TBI is located (Folta et al. 2006; Fritsch and Slavtchev 2011). TBIs located in those cities with a more entrepreneurial culture and support infrastructure are likely to have an advantage over those cities lacking in these respects. The 90 Chinese cities covered by our research are characterised by large disparities in terms of socio-economic development. Moreover, the inequalities between them have widened as the Chinese economy has grown. Our study combines unique TBI survey datasets with archival data relating to the socio-economic development of cities to compare the graduation performance of TBIs in three tiers of Chinese cities.

The rest of the paper is organised as follows. The next section explores the theoretical background and empirical evidence relating to the influence of TBIs' support services and venture capital on the performance of new technology-based firms, leading to hypotheses relating to their likely effects on the graduation of incubated firms. The datasets used for the empirical study are then introduced together with a description of our methodology. The modelling results are then presented and discussed before considering their implications for the future development of TBIs in China.

\section{Influence of TBIs' support services and venture capital on graduation performance}

Studies that examine the effects of an incubator on the successful development and growth performance of new technology-based firms have emphasised the importance of the incubator's support services (Mian 1996; Phan et al. 2005; Ratinbo and Henriques 2010; Lundqvist 2014). Some studies reveal that the links between the support services and new firm formation depend upon the local context in which an incubator is located (Cruz and Teixeira 2010; Zhang and Sonobe 2011; Hendry et al. 2000). The business incubator concept has had to adapt in order to fit varying local needs and conditions (Kuratko and LaFollette 1987) such that the degree of fit between the facilities and services offered by a TBI and the needs of the local economy is likely to be an important determinant of incubator success (Autio and Kloftsen 1998; Hackett and Dilts 2004).

There are a number of observations that can be made about existing research on TBIs which have influenced the direction of our study. First, Mian et al. (2016)carried out a survey of the existing literature and found that the most researched theme is incubator value added, covering tenant support, economic and regional development impact, and university-industry technology transfer. Second, previous studies tend to focus on one or more TBI case studies and are therefore unable to consider the effect of different contextual factors on the impact of TBIs. In other words, they do not provide comparative findings which take account of geographical variations that may contribute to the innovation activities and early growth performance of technology-based start-ups (Phan et al. 
2005; Cruz and Teixeira 2010). Third, the measure of performance used varies according the purpose of the research but may include the creation of incubatees, the extent of innovation activity, the graduation performance, and the subsequent survival and growth of incubated firms. For example, Rothaermel and Thursby (2005a) regard successful and timely graduation as an important milestone in an incubatees development but also warn that this is not a guarantee of subsequent success. Fourth, given that existing research is heavily focused on the western context, relatively little is known about whether the effects of TBI support services on the performance of the resident firms in Asian countries is the same as that in more developed countries. Finally, research has shown that the type of support services has evolved from offering a shared generic infrastructure for early stage firms operating in a variety of industrial sectors to shared tailored facilities for those operating in one/two specific industrial sectors (Allen and Rahman 1985; Hisrich and Smilor 1988; McAdam and McAdam 2008; Rothaermel and Thursby 2005b; Salvador 2011). Given the focus of much of the existing literature, it is now recognised that there is a need for research on the role that TBIs are playing in emerging and transition economies (Smith and Zhang 2012). This includes the need for investigation of the effects of TBI support services on the performance of incubated firms in different geographical contexts within China.

Whilst the allocation of resources to the specific support services that an incubator offers can be expected to be shaped by the rationale and objectives of each incubator, a key measure of success is likely to be the numbers of incubated firms that are considered to be sufficiently viable financially and commercially to be able to graduate from the incubator (Koh et al. 2005). Hackett and Dilts (2004) have developed and validated five incubator outcomes indicating the performance of incubated firms at the completion of the incubation process, based on data collected from 53 incubators operating in the US. They concluded in their study that the performance of firms and incubators can be reasonably measured by failure with small losses, failure with large losses, survival with no growth, survival with growth, and survival with growth and profitability. However, whilst they regard the latter three outcomes as indicative of incubation success, they acknowledge that they are no guarantee of future success or failure. A study focusing on the relationship between firm performance and university linkage by Rothaermel and Thursby (2005b) measured the performance of incubated firms, indicated by failure, graduation, or continued incubation within 3 years or less of entering the TBI. Our present study therefore focuses specifically on the graduation performance of TBIs, as measured by the number of incubated firms qualifying for graduation by reaching a level of sales turnover and profitability set by TBI senior managers.

\subsection{Support services}

TBI support services aim to improve the ability of resident firms to gain access to key resources and advice that they are not able to provide directly for themselves. Here, we are interested in those types of support service that are most likely to positively influence the number of firms that graduate from an incubator. There are three specific services relating to laboratory/research facilities, entrepreneurial mentoring, and financial support that are most likely to be associated with the early growth of new technology-based firms (Wright et al. 2008; Shrader and Siegel 2007) and which we focus upon:

Incubator technical service support An extensive literature focusing on TBIs associated with universities highlights the importance of resident technology-based start-ups being 
able to access a university's knowledge-based assets (Acs and Storey 2004; Audresch and Stephen 1996; Rothaermel and Thursby 2005b; Markman et al. 2005; Lundqvist 2014). TBIs associated with universities typically offer access to knowledge resources that are the product of research undertaken by academic staff and therefore owned by the universities (Mian 1996; Lofsten and Lindelof 2002; Siegel et al. 2003; Rothaermel and Thursby 2005b; Ratinbo and Henriques 2010). Recent studies also reveal that TBIs help their resident firms to build networks with academic scientists in order to increase the ability of the firms to access scientific knowledge resources (Bergek and Norman 2008; Jauhiainen 2008; Salvador 2011). Rothaermal and Thursby (2005b) studied 79 firms incubated in the Advanced Technology Development Centre at the Georgia Institute of Technology over a 6 year period from 1998 to 2003 and examined the role university linkages played in influencing failure or graduation of firms located in the incubator. Their results suggested that strong ties to the sponsoring university, indicated by licensed technology or university staff managing the business themselves, reduced the likelihood of failure but also retarded graduation from the incubator, whereas weak ties to the sponsoring university (e.g. information interaction with academic researchers) seemed not to influence outright firm failure or timely graduation.

Interestingly, research focusing on the Chinese context indicates no evidence that TBIs associated with a university lead to a better graduation performance than those not associated with a university (Zhang and Sonobe 2011). A study looking at incubators in Hong Kong reveals that resident firms do not benefit from the provision of network opportunities with scientists since most firms regard such links as of little relevance to their business development (Chan and Lau 2005). Those incubators that work closely with their resident firms are more likely to discover the laboratory, technical and research facilities that are most needed and can be shared with other firms in the incubator (Aerts et al. 2007). An incubator's financial resources may therefore be used to establish such facilities which compensate for limited access to technical resources and testing facilities from the local economy. A shared research infrastructure is likely to include industrial and production testing services, expensive equipment for scientific data sharing and professional technical services. The established research infrastructure enables young technology-based firms to gain access to the facilities and equipment which otherwise would be unaffordable and thus reduce the incubation time and their R\&D/operation costs. A good indication of the scale of the technical service support offered by an incubator is the amount of financial resources invested in these facilities.

The better the technical infrastructure, the more conducive an incubator environment is likely to be for the establishment of technology-based firms, their early growth and innovativeness and readiness to graduate from the incubator. We therefore propose:

H1 The graduation performance of TBIs is positively associated with the total amount invested in the technical services support.

Incubator entrepreneurial service support The literature on the support services offered by incubators has recently paid more attention to entrepreneurial competencies (Hjelm and Borgman 2004). Lundqvist (2014) studied 170 incubated firms in 16 Swedish university incubators over an 11 year period from 1995 to 2005 and examined the role of surrogate entrepreneurship i.e. the contribution that experienced entrepreneurs from outside the incubator played in influencing the performance of resident firms. The results suggested that new technology-based firms that recruited a surrogate entrepreneur enjoyed a better performance indicated by employment and revenue growth compared to non-surrogate 
firms. This is consistent with the view that many SMEs in general and technology-based SMEs in particular suffer from a lack of the business and management skills required to operate a business successfully and to access the resources needed to grow the business (Lyon et al. 2000; Hjelm and Borgman 2004). McAdam and Marlow (2011) found that experienced entrepreneurs help early stage technology-based ventures improve their ability to obtain venture capital by making sense of the funding application and presenting it convincingly to investors. Incubators therefore provide entrepreneurial assistance to earlystage technology-based firms through bringing in experienced entrepreneurs to work with incubated firms (Bollingtoft and Ulhoi 2005). For their part, experienced entrepreneurs who are looking for business investment opportunities could also benefit from working closely with early-stage technology-based firms. The number of experienced entrepreneurs who play a mentoring role may provide a useful indicator of the level of practical business skills that an incubator offers to early-stage technology-based firms. Therefore, we expect that:

H2 The graduation performance of TBIs is positively associated with the number of mentors that provide entrepreneurial service to incubators firms.

Incubator financial support One of the biggest challenges confronting new technologybased firms is being able to access various sources of finance in order to facilitate the early growth of the business (Carpenter and Petersen 2002; Oakey 2003; North et al. 2013; Xiao and North 2012). The literature suggests that a key factor accelerating the development of technology-based firms is the attraction of sufficient amounts of investment to those projects helping to commercialise technological achievements (Acs and Audretsch 1998; Colombo et al. 2010; Perez-luno et al. 2011). TBI managers may choose to do this by providing direct financial support to technology-based start-up firms themselves (Aerts et al. 2007; Bruneel et al. 2012). In addition, they may help resident firms build up networks with suppliers of finance (e.g. business angels and venture capitalists), thus improving their ability to gain access to external finance (Salvador 2011).

Direct financial support from a TBI to technology-based firms has been shown to be particularly important in shortening the time needed to fully develop, test, commercialise and launch innovative products on to the market and thereby have a positive effect on the number of firms graduating from a TBI (Branscomme and Auerswald 2002). This can be essential in contexts where there is a dearth of other external sources of funding (Markman et al. 2005; Xiao and North 2012). Incubator finance could be the only external finance source available to young technology-based firms, which are likely to be seen as very high risk investments, particularly at the start-up stage of business development. In addition, receipt of finance from an incubator could provide a positive signal to other potential suppliers of finance, reducing the risk associated with investing in new ventures and therefore putting the firm in a better position to attract external funding.

Direct financial support from an incubator to resident firms can help to accelerate the early growth of technology-based firms. Hence the amount of funding that is available to technology-based start-ups within an incubator is likely to be an important determinant of the TBI's graduation performance. We would expect that:

H3 The graduation performance of TBIs to be positively associated with the amount of financial support available to new technology-based firms within an incubator. 


\subsection{Venture capital}

Venture capital is generally considered to be more appropriate than loan finance in funding new technology-based firms because of problems of information asymmetry associated with assets being intangible and knowledge based (Bertoni et al. 2010; North et al. 2013). In western countries, incubators that aim at improving the ability of early-stage technology-based firms to gain access to venture capital have been placing emphasis on building networks with both business angels and venture capitalists (Aerts et al. 2007; Bruneel et al. 2012). Moreover, young technology-based firms that have a close relation with business angels and/or venture capitalists may be in a better position to source other finance and gain entrepreneurial expertise (Wright et al. 2004). Ahlstrom and Bruton (2010) report that in transition economies informal investors usually employ a network-based approach to assess an investment opportunity. Evidence suggests that equity finance from informal investors tends to be highly 'local' in origin in both more advanced and emerging economies (Colombo et al. 2010; Xiao and Ritchie 2011). For these reasons, the availability of venture capital to technology-based start-up firms is likely to depend on the geographical context (Colombo and Delmastro 2002).

Research focusing on financing technology-based firms in the USA found that the attraction of venture capital enabled early-stage technology-based firms to speed up R\&D and the product innovation process, meet the financing demands imposed by growth, and improved their chances of survival and growth (Cooper et al. 1994). A study looking into technology-based start-ups located in American university incubators found that obtaining venture capital was the key to accelerating their early-stage growth (McAdam and McAdam 2008). Colombo and Grilli (2010) found that venture investors providing finance to young technology-based firms in Italy also generally played a 'coaching' role in offering additional resources and capabilities that drove the growth of their portfolio firms. In the Chinese context, it remains unclear whether informal investors who play an increasingly important role in providing equity finance to young technology-based firms contribute positively in other ways as well (Xiao and North 2012). Nevertheless, it has been generally agreed that the availability of venture capital has been a necessary although not sufficient requirement for the growth of new technology-based firms (Colombo and Grilli 2010). We therefore propose:

H4 The graduation performance of TBIs is positively associated with the amount of venture capital received by new technology-based firms within an incubator.

\section{Methodology}

\subsection{The three tier Chinese cities}

Four decades of implementing policies under the initiative'the reform and opening' designed to open up the Chinese economy to world trade and competition has led to marked disparities in the levels of economic and social development between cities (Dollar 2007). It has been argued that these disparities have been exacerbated by the decentralisation of control of universities to local government as this has favoured knowledge transfer in those cities with leading universities and research institutes and marginalised those cities in less favoured regions previously relying on central government for knowledge support (Hong 2008). These geographical disparities suggest that those TBIs 
and incubated firms located in the more advanced and wealthy cities benefit from the greater abundance of those resources required for creating and supporting technologybased business including sources of finance, an educated workforce, and a supportive business climate compared to those located in the less prosperous and lagging cities. Our study addresses this issue through a comparison of the various influences on the graduation performance of TBIs across 90 Chinese cities.

The first TBI, Wuhan Donghu Pioneers Centre was formally established in 1987 and was located close to Wuhan University, one of the leading universities situated in the Central region of China. Since its establishment the Centre has been a model for other major Chinese cities mainly in the Eastern region. Approximately 30 TBIs were created over a period of 2 years between 1989 and 1990. By 1997, 80 TBIs had been established and were disproportionately centred on five Eastern provinces (Beijing, Suzhou, Shanghai, and Tianjin), one Central province (Wuhan), and three Western provinces (Xi'an, Chengdu, and Chongqing), supporting 2670 tenant firms with 45,600 employees (China Torch Statistical Yearbook 2000). Recently, more TBIs have been established in a wide range of Chinese cities, taking advantage of a business environment more conducive to technology-based start-ups. Both the more and less wealthy cities have encouraged private investors to establish TBIs by making use of abandoned state-owned plants that may not be near to leading universities. The geographic distribution pattern of TBIs remains focused on the more advanced cities and this also applies to the establishment of the latest generation of specialised business incubators (i.e. industry-specific, university-related, and international incubators).

In order for us to examine the graduation performance of TBIs at the city scale, we draw upon China's latest city tier system which captures each city's economic development level, economic position relative to the country and region, and its historic and cultural significance. It has been widely used in the media and is now generally accepted by business people and citizens. By combining the commonly accepted tier city system with our TBI distribution, we group the 90 Chinese cities hosting a total of 215 TBIs in our study into the three tiers of cities. Tier 1 cities include the four most affluent cities namely: Beijing, Shanghai, Guangdong, and Shenzhen. Tier 2 comprises 15 cities in the more advanced provinces namely: Chengdu, Chongqing; Dalian, Hangzhou, Ningbo, Kunming, Nanjing, Suzhou, Wuxi, Qingdao, Tianjin, Zhuhai, Wuhan, Xiamen, Xi'an. The remaining 71 cities comprise Tier 3 . As Table 1 shows, we found considerable differences in GDP per capita between the three tier cities.

\subsection{Data and variables}

This study makes use of (1) survey data on all TBIs and new technology-based firms within each of the TBIs in China, (2) official data sources and (3) hand-collected data from TBIs' websites. The survey data was collected by the Ministry of Science and Technology (MOST) for China in five consecutive annual surveys undertaken from 2009 to 2013. We have restricted our subsequent analysis to the 215 TBIs that existed in 2009 and participated in all five successive surveys. The secondary data (i.e. the number of universities within the host city of each TBI and GDP per capita at a city level) was collected from Statistical Yearbooks produced by various levels of government. We also collected data relating to each TBI (i.e. the ownership and age of TBIs) from their websites. Table 2 shows the incubator and firm distribution by city tier. It reveals that the four tier 1 cities host $24 \%$ of the total TBIs, which are older and smaller (measured by the number of resident firms) than those in the tier 2 and tier 3 cities. It also shows that there are 150 
Table 1 GDP (Yuan) by city tier (2013)

\begin{tabular}{|c|c|c|c|c|c|c|c|c|}
\hline & \multicolumn{4}{|c|}{ GDP per capita } & \multicolumn{4}{|l|}{ GDP } \\
\hline & Mean & Std.Dev & Min & $\operatorname{Max}$ & Mean & Std.Dev & Min & Max \\
\hline Tier 1 & $93,097.47$ & $15,434.59$ & $83,390.27$ & 125,026 & $16,142.37$ & 2525.86 & $12,423.44$ & $19,195.69$ \\
\hline Tier 2 & $73,184.67$ & $21,392.11$ & $19,244.58$ & $107,964.6$ & 6870.71 & 2439.69 & 1404.93 & 11,459 \\
\hline Tier 3 & $51,763.67$ & $24,485.72$ & 9275.08 & $131,496.6$ & 2822.27 & 1440.71 & 284.96 & 6059.24 \\
\hline Total & $67,745.65$ & $24,469.56$ & 9275.08 & $131,496.6$ & 7109.50 & 5657.63 & 284.96 & $19,195.69$ \\
\hline
\end{tabular}

Notes Calculated according to Statistics Yearbooks 2013 by government at national, provincial, and city level

government TBIs, 46 private TBIs, and 19 university TBIs in our sample. The larger size of TBIs in the tier 2 and tier 3 cities may reflect the fact that some of them still operate like the first generation state owned and managed TBIs with new ventures operating in various industrial sectors and a strong focus on new business formation rather than on supporting innovative ventures with high growth potential. Moreover, it enables this work to examine the relations between the three incubator factors and the graduation performance of the incubated firms.

Table 3 provides a summary of the definitions and descriptive statistics for the variables used in this study. These comprise:

Dependent variable As discussed earlier, an important function of incubators is to improve the early growth of technology-based start-up firms and ensure that these firms become established in the market without further support from the incubator. Our work uses the number of firms that met the graduation requirements and left the incubator as an indication of success. TBIs generally follow the guidelines set by the MOST in judging whether an incubatee is ready to graduate, taking account of sales turnover, profit, asset size, and giving particular recognition to high-tech firms. The application of these criteria is made by each TBI's managers and will vary depending upon industrial sector and each incubatee's circumstances. For firms that decide that they want to go it alone, this would count as a graduation only in a situation where they have reached the required threshold levels. New technology-based firms that meet the graduation criteria are considered to reach a certain level of competitiveness 'vis-a-vis' their counterparts in the market without further support being required from the incubator.

Independent variables These include the three incubator-specific support services and venture capital. The direct financial support (InFund) provided by an incubator is measured by the total amount of incubator funding available to all the resident firms. The scale of technical support (Techinvestment) is indicated by the amount of investment in laboratories, technical and research facilities to be used by incubated firms. The level of entrepreneurial mentoring (ENTR) is measured by the total number of experienced entrepreneurs who work with the resident firms. The availability of venture capital (VC) is measured by the total amount of venture capital received by all the resident firms within an incubator.

Control variables We consider (a) TBI controls i.e. incubator size (Size), incubator age (Age), ownership type, (Type), and (b) external control i.e. number of universities and colleges (No.Uni) since these variables are likely to influence the graduation performance 


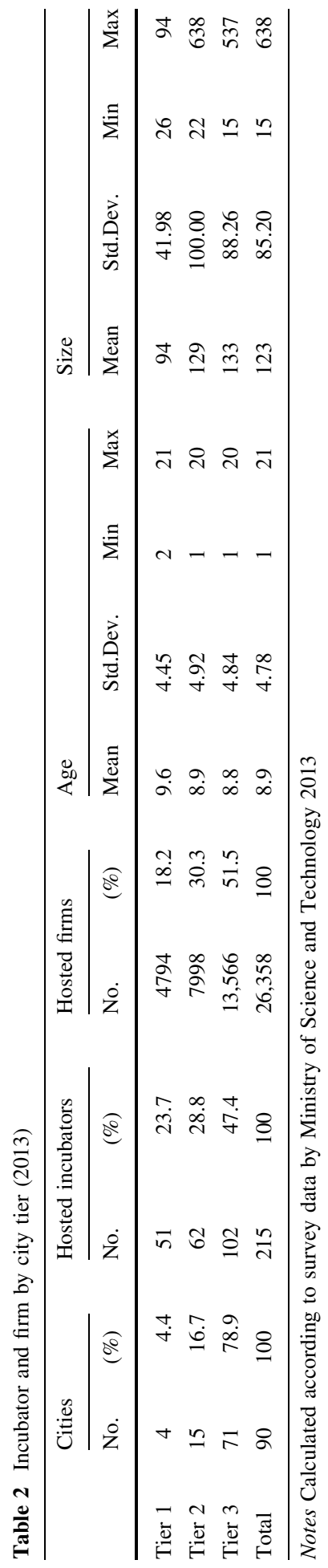


Table 3 Variable definition and summary statistics (2009-2013)

\begin{tabular}{|c|c|c|c|c|c|c|}
\hline Variable & Definition & Mean & Minimum & Maximum & $\begin{array}{l}\text { Standard } \\
\text { deviation }\end{array}$ & $\begin{array}{l}\text { No. of } \\
\text { observations }\end{array}$ \\
\hline \multicolumn{7}{|l|}{ Dependent variable } \\
\hline NGF & $\begin{array}{l}\text { Total number offirms } \\
\text { met graduation } \\
\text { criteria and left the } \\
\text { incubator }\end{array}$ & 11.56 & 1.0 & 137 & 10.87 & 1095 \\
\hline \multicolumn{7}{|c|}{ Independent variables } \\
\hline $\begin{array}{l}\text { InFund (1000 } \\
\text { Yuan) }\end{array}$ & $\begin{array}{l}\text { The amount of } \\
\text { incubator funding that } \\
\text { is available to all the } \\
\text { resident firms }\end{array}$ & 21,480 & 100 & $5,000,000$ & 164,357 & 1095 \\
\hline $\begin{array}{l}\text { Techinvestment } \\
\text { (1000 Yuan) }\end{array}$ & $\begin{array}{l}\text { The amount of } \\
\text { investment in the } \\
\text { public service } \\
\text { platform }\end{array}$ & 12,586 & 4 & 195,800 & 12,587 & 1095 \\
\hline ENTR & $\begin{array}{l}\text { The number of } \\
\text { entrepreneurs playing } \\
\text { a role of mentoring } \\
\text { the firms }\end{array}$ & 10 & 1 & 158 & 12.17 & 1095 \\
\hline VC (1000 Yuan) & $\begin{array}{l}\text { The amount of venture } \\
\text { capital received by } \\
\text { the firms }\end{array}$ & 84,273 & 1 & $1,900,000$ & 198,858 & 1095 \\
\hline \multicolumn{7}{|l|}{ Control variables } \\
\hline Size & $\begin{array}{l}\text { Total number of firms } \\
\text { within each incubator }\end{array}$ & 123 & 15 & 638 & 85.19 & 1095 \\
\hline Age & $\begin{array}{l}\text { The year an incubator } \\
\text { started incubating } \\
\text { firms }\end{array}$ & 9 & 1 & 21 & 4.78 & 1095 \\
\hline No.Uni & $\begin{array}{l}\text { The number of } \\
\text { universities within in } \\
\text { a city }\end{array}$ & 37 & 2 & 91 & 28.00 & 1095 \\
\hline
\end{tabular}

Notes Average statistics of each variable exclude observation where its value were 0 over the period 2009-2013

as measured by the number of firms that met the criteria and left the incubator. The number of incubated technology-based firms resident within an incubator is used to indicate size. Age is measured from the year an incubator started incubating firms. Literature on incubators maintains that the TBI ownership influences the overall objectives, resources available internally and externally, management team composition, and the allocation of resources to specific support services to facilitate the early growth of new technologybased ventures (Pauwels et al. 2016). We therefore distinguish between three types of TBI in our regression modelling to examine if there are any differences between them in the effects of the three support services on the early growth of new technology-based ventures. The three types of TBI ownership are government TBIs, university TBIs, and private TBIs. Government TBIs refer to those funded by central, provincial, and local government, and operated by a government agency whereas university TBIs refer to those funded by 
government but operated by a management team from a university. The scale of scientific knowledge resources (No.Uni) is indicated by the number of universities and colleges located in the host city of each TBI. We use this number to indicate the local availability of technology resources, which may influence relations between support services and the early stage of new ventures.

\subsection{Data analysis}

The hypotheses proposed earlier are estimated by the Maximise Likewise Estimation (MIE) and tested with negative regression models for each set of independent variables. As the dependent variable is count rather than continuous data, negative binomial regression is the most appropriate model to use. We first conduct regression tests for the entire sample and then repeat the models for the tier 1, tier 2, and tier 3 cities in order to investigate whether there are any differences in the effects of incubator factors and venture capital between the three tier cities. The same test is also conducted for the three ownership types of TBI.

\section{Empirical results}

\subsection{Entire sample}

In Table 4, we report the results of negative binomial regression analysis to examine the effects of incubator funding, technical support facilities and entrepreneurial mentoring as well as venture capital on the number of incubated firms that graduated over the 2009-2013 period. Model 1 applies to the entire national sample of TBIs and resident firms and covers the three incubator specific factors i.e. the magnitude of incubator funds (InFund); the amount invested in the shared laboratory and technology platform (Techinvestment); the number of mentors providing entrepreneurial expertise to the resident firms (ENTR); venture capital (VC); and three control variables including incubator size and age as well as number of universities located in the host city of each TBI (Size, Age, and No.Uni).

Interestingly, as model 1 shows, we find that the amount of incubator funding that is available to new technology-based firms located in each incubator has no statistically significant effect on the number of graduated firms, controlling for incubator size and age as well as the number of universities in the host city. The amount of investment in the shared laboratory and technical service platform for the use of resident firms at no or low cost does have a statistically significant $(p<.01)$ and positive effect on the number of firms that met the graduation criteria and left the incubator. This could be because spending on the technical support services brings forward the time that it takes to produce marketable products or services. The number of mentors helping the firms also has a statistically significant and positive effect on the number of firms graduating $(p<.05)$. This indicates that the entrepreneurial expertise provided by incubators to advise the ownermanagers of incubatees does play an essential role in helping the early development of new technology-based firms. Table 4 also shows that the amount of venture capital received by incubatees does have a significant $(p<.01)$ and positive effect on the early growth of new technology-based firms as indicated by the number of firms that graduate. This finding suggests that those investors that provide equity finance seek out those resident firms with 


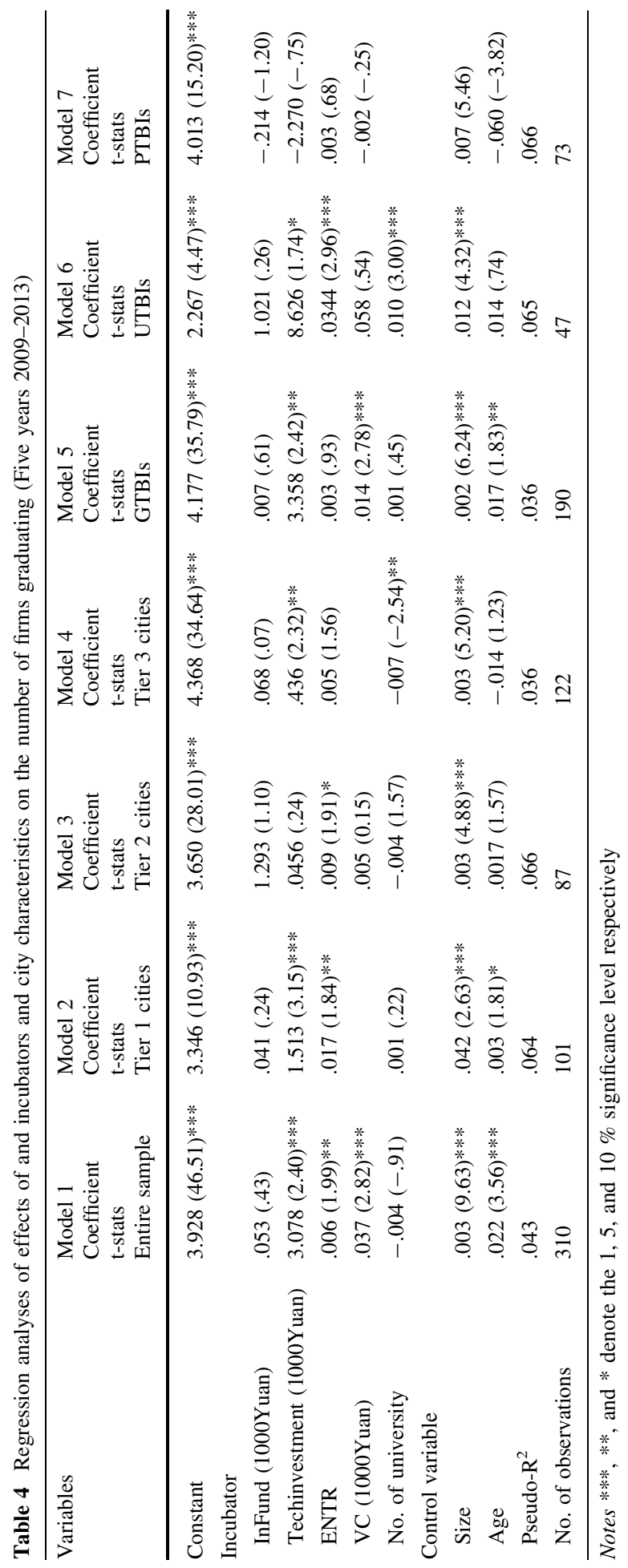


growth potential and may also offer hands-on assistance to speed up their growth. Model 1 also confirms that the number of graduated firms is positively influenced by incubator size and age $(p<.01$ and $p<.01)$, but not affected by the size of the local scientific knowledge base as measured by the number of universities in the host city.

\subsection{Differences between three tier cities}

We now repeat the above regression models to see if there are any differences in the effects of incubator factors and venture capital between the three tiers of cities. As discussed earlier, we have used this threefold classification for the 90 cities hosting the 215 TBIs included in this study: models 2, 3 and 4 relate to the TBIs located in the tier 1, tier 2 and tier 3 cities respectively.

As shown in Table 4, we find some differences in the results for the cities in the three tiers. We first look into the incubator funding available to resident firms. As models 2, 3, and 4 show, we find that this has no significant influence on the number of graduating firms across all three tiers, being consistent with the regression results for the entire sample. Thus direct financial support from an incubator appears not to result in more firms meeting the graduation criteria and leaving an incubator. This could be because incubator funding (e.g. in the form of a grant related to the amount of $\mathrm{VC}$ received or payment towards a patent application) is carefully directed towards either a few fast growing firms that have proved their competitive advantages and/or a few advanced $R \& D$ projects that promise to result in highly innovative ventures (Xiao and North, 2013).

We now turn to consider investment in the shared laboratory and technical facilities and control for size, age, and the number of universities in the host city. Interestingly, models 2 and 4 reveal that the effect of investment in the technical service platform on the number of firms that met graduation criteria and left the incubator is statistically significant and positive in both the tier 1 cities $(p<.01)$ and tier 3 cities $(p<.05)$, whilst model 3 shows no significant effect in the tier 2 cities. As far as the most developed cities are concerned, this is possibly an indication that a significant proportion of TBIs have focused on a specific industry, building upon local economic strengths, thereby increasing the effectiveness of investment in the technical service platform as reflected in the number of incubatees graduating.

In terms of the number of entrepreneurial mentors, models 2 and 3 for the tier 1 and tier 2 cities show that the graduation of new technology-based firms is positively and significantly $(p<.05$ and $p<.10)$ influenced by the scale of entrepreneurial support. However, as model 4 shows, this appears not to apply to the TBIs in the tier 3 cities. This would seem to indicate that entrepreneurial support increases the number of resident firms that are ready to graduate in the tier 1 and tier 2 cities by better strengthening business capabilities and market readiness compared to the experience of TBIs in the tier 3 cities.

We now repeat the above regression models to see if the effects of incubator services and venture capital differ between government, university, and private TBIs. As shown in Table 4, models 5, 6 and 7 refer to the government TBIs, university TBIs, and private TBIs respectively. We find some interesting differences in the results for the three types of TBI.

As all three models show, the amount of incubator funding has no significant influence on the number of graduating firms across all three types of TBIs, this being consistent with the regression results for the entire sample and the three tiers of cities. With respect to technical service support, the effect of investment in the technical service platform on the number of firms that met graduation criteria and left the incubator is statistically significant and positive in both government TBIs $(p<.05)$ and university TBIs $(p<.1)$, whilst there 
is no significant effect in private TBIs. This confirms that both government and university TBIs received funding from public sources much of which they invested in shared laboratory, research and technical facilities to help the early development of new ventures. With much less public funding, it is possible that the private TBIs prioritised (1) rentseeking to cover their operation expenses, even if it meant holding onto tenants rather than helping them to graduate; or (2) the selection of entrepreneurs who are likely to be more self-sufficient in terms of resourcing and accessing expertise. With regards to entrepreneurial mentoring, model 6 for the university TBIs shows that the graduation of new technology-based firms is positively and significantly $(p<.01)$ influenced by the scale of entrepreneurial support. However, as models 5 and 7 show, this appears not to apply to the other types of TBI. This could indicate that the founding entrepreneurs of resident firms located in university TBIs are more likely to possess scientific or technological expertise but lack entrepreneurial experience and business acumen compared to their counterparts in government or private TBIs.

Concerning venture capital, we find that it has a significant influence on the numbers of firms graduating from the government TBIs, as shown in Table 4. One possible explanation could be that the financial incentives provided by government TBIs are quite often linked to obtaining VC externally, thereby encouraging resident firms to actively seek out sources of VC. It is perhaps surprising that VC does not emerge as a significant influence upon graduation in the private TBIs as we might have expected one of the advantages of locating in this type of TBI to be the private owner's ability to network with potential investors.

Turning to the number of universities located in a host city, we find no significant effect in the tier 1 and tier 2 cities on the number of firms graduating, but a negative and significant effect in the tier 3 cities. Interestingly, model 6 shows a significant positive influence for university TBIs. It is perhaps unsurprising that incubated firms' linkages with universities are stronger within university TBIs compared to those firms within government and private TBIs. Although it is interesting to note here that Rothaermel and Thursby (2005b) found in their US research that strong ties to the sponsoring university in the form of licensed technology, intellectual property rights, and academic staff managing the businesses tended to retard graduation from the incubator.

Taken together, these findings suggest that TBIs in the tier 1 cities are more capable of helping the early development of new ventures by spending on technical support services including shared laboratory and research facilities compared to their counterparts in the tier 2 and tier 3 cities, as indicated by the number of firms graduating. Entrepreneurial mentoring is also a key influence on the number of firms graduating in the tier 1 and tier 2 cities. So the level of economic development reached by a city that hosts TBIs would seem to matter to the graduation of new technology-based firms. Models 5, 6, and 7 also suggest that the effects of incubator factors on the early development and graduation of incubated firms are associated with the ownership type of the TBI.

\section{Conclusions and policy implications}

This paper empirically compares the influence of three incubator support services on the graduation performance of incubated firms by use of a dataset comprising 215 TBIs operating over five successive years from 2009 and distributed across 90 Chinese cities grouped into three tiers according to their level of development. As such, it makes three 
contributions to the literature. First it addresses the plea (e.g. Phan et al. 2005; Mian et al. 2016) for more international research on TBIs by being one of the few studies to date to focus on their role within China, a fast growing Asian transition economy. Second, much of the existing research on TBIs focuses on detailed evidence from single or multiple case studies, limiting the possibility of generalising results beyond a specific context (McAdam et al. 2016). Using government survey data covering TBIs throughout China, our research has been able to examine TBIs in different geographical contexts reflecting the marked regional disparities that exist within the country. And third, whilst previous studies have drawn attention to the wide range of mechanisms and operational practices found amongst TBIs, our research advances our understanding of the role played by TBIs in supporting the early development of new technology-based firms by examining three incubator services that have been shown to be the most needed by new technology-based firms in Asian countries (Chan and Lau 2005; Zhang and Sonobe 2011).

Of the three incubator specific services, we have found that the most influential one in speeding up the early development of resident firms is investment in the technical support platform, including the provision of shared laboratory, research and technical facilities, followed by entrepreneurial mentoring. In other words, it is the technical and entrepreneurial assistance provided by TBIs that plays a particularly important role in speeding up the early development of new technology-based firms to a point where they are able to graduate from the incubator. Incubated firms benefit from the shared facilities and entrepreneurial mentoring in order to reach a level where they can survive and grow without any further assistance from a TBI (Lundqvist 2014; Rothaermel and Thursby 2005a). In contrast, any direct financial support that TBI managers are able to give resident firms appears not to have improved graduation performance overall. According to TBI managers themselves, their financial assistance, perhaps in the form of grant or equity finance, has been largely directed towards supporting either radical innovation activities or a few fast growing firms. Indeed, as commented elsewhere (Xiao and North 2013), it was often the intention of TBI managers to focus their financial assistance on a relatively small number of firms which they considered to have the potential to become leading market players, not least because this boosted their own self-image and reputation.

With regards to possible differences between the three tier cities, our results point to some differences in the effectiveness of the three most established services provided by incubators on the early development of incubated firms. We also found that TBI ownership plays a role in influencing relations between support services and early development of new ventures. Regression estimates show no associations between the amount of incubator direct funding and the number of graduated firms across all three tier cities and all three types of TBI. In the top four affluent cities and the tier 3 cities, investment in the technical services platform does have a positive and significant effect on the early development and graduation of new ventures whereas entrepreneurial assistance contributes to the early development of incubated firms in the tier 1 and tier 2 cities. The combination of public investment in shared research and technical facilities and entrepreneurial mentoring appear to be most effective in influencing the number of firms graduating from TBIs in the most advanced cities where the external conditions are most conducive to new venture creation anyway. Further research should explore whether the differences in the effects of the support services provided by TBIs on the early development of new technology-based firms are due to other contextual factors and/or gaps [e.g. incubators in less developed cities 
have difficulties in focusing on a main technology theme (Chan and Lau 2005)] that amplify or abate the effect of the TBIs' own efforts.

Our empirical results give rise to some important policy implications for governments at the national and provincial level as well as for incubator management teams. First, whilst our findings indicate that both the technical and entrepreneurial support provided by Chinese TBIs have a positive effect on the early development of technology based firms and their graduation from the incubator, it nevertheless raises an important question as to whether this is leading to the formation of those kinds of businesses (e.g. in the digital and media sectors) which do not require long periods of R\&D and testing before launching products to the market. In other words, are other kinds of business (e.g. in the life sciences, bio-tech, and alternative technologies sectors) that are more likely to undertake advanced, higher level innovations being adversely affected by the emphasis given to these TBI support services. Admittedly such a change of emphasis may result in fewer firms graduating over a period of time, although those that do might have greater growth potential in the long term.

Second, recording the number of firms that graduate from TBIs is a key measure that MOST, provincial, and local governments use for measuring the success of TBIs in China. Yet because an incubatee has satisfied the stipulated graduation criteria (sales level, profitability etc.), it does not guarantee the launch of a successful business (Rothaermel and Thursby 2005a). In research on post-graduation survival conducted in East Germany, (Schwartz 2009) drew attention to a high risk period starting with the completion of incubation and lasting up to 3 years after leaving the incubator. His evidence showed that just under a third of firms were unlikely to survive a period of 6 years after graduation. Without further research focused on the post-graduation experience, we have no means of knowing from existing data sources what has happened to graduating firms from Chinese TBIs and whether the long term survival rates are any different from those found in western countries.

Third, our evidence shows that technical support services involving shared laboratory and research facilities tend to work best in the tier 1 cities where TBIs have become more specialised in a particular industrial sector and where there has been a constant flow of incoming and outgoing firms. In this respect Chinese TBIs are following the path of incubator development in western countries where it has been found that building knowledge networks and realising opportunities that meet the needs of resident firms is leading to increased incubator specialisation (Dee et al. 2011). This development path also implies that TBIs become more selective in the ventures that they accept. The more limited impact of TBI services on the graduation of incubated firms in the tier 2 and tier 3 cities indicates that the TBIs in these less favourable economies face more difficult challenges if they are to help the early development of new tehnology-based firms.

Finally, future research should attempt to go beyond what has been possible in this study. Although our research has benefited from being based on a large secondary source dataset covering all TBIs in China over a recent 5 year period, it has been constrained by the way the various TBI inputs and outputs have been measured by the Chinese authorities. For instance, the direct financial support from an incubator to the incubated firms is measured by the amount of incubator funding available to the firms rather than how these resources have been allocated and in what form (e.g. grant, interest free loan, equity finance,) More in-depth primary research that focuses on a sample of TBIs in different types of city is now required in order to advance our understanding of their role in China's economic transformation. 
Open Access This article is distributed under the terms of the Creative Commons Attribution 4.0 International License (http://creativecommons.org/licenses/by/4.0/), which permits unrestricted use, distribution, and reproduction in any medium, provided you give appropriate credit to the original author(s) and the source, provide a link to the Creative Commons license, and indicate if changes were made.

\section{References}

Acs, Z. J., \& Audretsch, D. B. (1998). Innovation in large and small firms: An empirical analysis. American Economic Review, 78, 678-690.

Acs, Z., \& Storey, D. J. (2004). Introduction: Entrepreneurship and economic development. Regional Studies, 38, 871-877.

Aernoudt, R. (2004). Incubators: Tool for entrepreneurship? Small Business Economics, 23, 127-135.

Aerts, K., Matthyssens, P., \& Vandenbempt, K. (2007). Critical role and screening practices of European business incubators. Technovation, 27, 254-267.

Ahlstom, D., \& Bruton, G. (2010). Rapid institutional shifts and the co-evolution of entrepreneurial firms in transitional economies. Entrepreneurship Theory and Practice, 34, 531-554.

Allen, D. N., \& Rahman, S. (1985). Small business incubators: A positive environment for entrepreneurship. Journal of Small Business Management, 23, 12-22.

Audresch, D. B., \& Stephen, P. E. (1996). Company-scientist location links: The case of biotechnology. The American Economic Review, 86, 641-652.

Autio, E., \& Kloftsen, M. (1998). A comparative study of two European business incubators. Journal of Small Business Management, 36, 30-43.

Bergek, A., \& Norman, C. (2008). Incubator best practices: A framework. Technovation, 28, 20-28.

Bertoni, F., Croce, A., \& D'Adda, D. (2010). Venture capital investments and patenting activity of high-tech start-ups: A micro-econometric firm-level analysis. Venture Capital, 12, 307-326.

Bollingtoft, A., \& Ulhoi, J. P. (2005). The networked business incubator-leveraging entrepreneurial agency? Journal of Business Venturing, 20, 265-290.

Branscomme, L. M., \& Auerswald P. E. (2002). Between invention and innovation: An analysis of funding for early-stage technology development. Gaithersburg, MD: Report for National Institute of Standards and Technology, 112002.

Bruneel, J., Ratinho, T., Clarysse, B., \& Groen, A. (2012). The evolution of business incubators: Comparing demand and supply of business incubation services across different incubator generations. Technovation, 32, 110-121.

Carpenter, R. E., \& Petersen, B. C. (2002). Is the growth of small firms constrained by internal finance? The Review of Economics and Statistics, 84, 298-309.

Chan, K. F., \& Lau, T. (2005). Assessing technology incubator programs in the science park: The good, the bad and the ugly. Technovation, 25, 1215-1228.

China Statistic Press. (2000). China Torch Statistical Yearbook 2000. Beijing: China Statistic Press.

Colombo, M. G., \& Delmastro, M. (2002). How effective are technology incubators? Evidence from Italy. Research Policy, 31, 1103-1122.

Colombo, M. G., \& Grilli, L. (2010). On growth drivers of high-tech start-ups: Exploring the role of founders' humancapital and venture capital. Journal of Business Venturing, 26, 610-626.

Colombo, M. G., Luukkoner, T., Mustart, P., \& Wright, M. (2010). Introduction: Venture capital and hightech start-ups. Venture Capital, 12, 261-266.

Cooper, A. C., Gimeno-Gascon, F., \& Woo, C. (1994). Initial capital and financial capital as predictors of new venture performance. Journal of Business Venturing, 9, 371-395.

Cruz, S. C., \& Teixeira, A. A. C. (2010). The evolution of the cluster literature: Shedding light on the regional studies- regional science data. Regional Studies, 44, 1263-1288.

Dee, N. J., Livesey, F., Gill, D. \& Minshall, T. (2011). Incubation for growth: A review of the impact of business incubation on new ventures with high growth, Nesta Report.

Dollar, D. (2007). Poverty, inequality, and social disparities during China's economic reform, World Bank policy working paper.

Ferguson, R., \& Olofsson, C. (2004). Science parks and the development of NTBFs location, survival and growth. The Journal of Technology Transfer, 29, 5-17.

Folta, T., Cooper, A. C., \& Y-S, Baik. (2006). Geographic cluster size and firm performance. Journal of Business Venturing, 21, 217-242.

Fritsch, M., \& Slavtchev, V. (2011). Determinants of the efficiency of regional innovation systems. Regional Studies, 45, 905-918. 
Hackett, S. M., \& Dilts, D. M. (2004). A real options-driven theory of business incubation. Journal of Technology Transfer, 29, 41-54.

Hansen, M. T., Chesbrough, H. W., Nohria, N., \& Sull, D. N. (2000). Networked incubators. Harvard Business Review, 78, 74-84.

Hendry, C., Brown, J., \& Defillippi, R. (2000). Regional clustering of high technology-based firms: Optoelectronics in three countries. Regional Studies, 34, 129-144.

Hisrich, R., \& Smilor, R. (1988). The university and business incubation: Technology transfer through entrepreneurial development. The Journal of Technology Transfer, 13(1), 14-19.

Hjelm, P. B., \& Borgman, B. (2004). Geographical concentration, entrepreneurship and regional growth: Evidence from regional data in Sweden, 1975-1999. Regional Studies, 38, 929-947.

Hong, W. (2008). Decline of the center: The decentralizing process of knowledge transfer of Chinese universities from 1985 to 2004. Research Policy, 37, 580-595.

Jauhiainen, J. S. (2008). Regional and innovation policies in Finland-towards convergence and/or mismatch? Regional Studies, 42, 1031-1045.

Koh, F. C. C., Koh, W. T. H., \& Tschang, F. T. (2005). An analytical framework for science parks and technology districts with an application to Singapore. Journal of Business Venturing, 20, 217-239.

Kuratko, D. F., \& LaFollette, W. R. (1987). Small business incubators for local economic development. Economic Development Review, 5, 49.

Lofsten, H., \& Lindelof, P. (2002). Science parks and growth of new technology based firms: Academicindustrial links, innovation and markets. Research Policy, 31, 859-876.

Lundqvist, M. A. (2014). The importance of surrogate entrepreneurship for incubated Swedish technology ventures. Technovation, 34, 93-100.

Lyon, D. W., Lumpkin, G. T., \& Dess, C. G. (2000). Enhancing entrepreneurial reindentation research: Operationalising and measuring a key strategic decision making process. Journal of Management, 25, 1055-1085.

Markman, G. D., Phan, P. H., Balkin, D. B., \& Gianiodis, P. T. (2005). Entrepreneurship and universitybased technology transfer. Journal of Business Venturing, 20, 241-263.

McAdam, M., \& Marlow, S. (2011). Sense and sensibility: The role of business incubator client advisors in assisting high-technology entrepreneurs to make sense of investment readiness status. Entrepreneurship and Regional Development, 22, 449-468.

McAdam, M., \& McAdam, R. (2008). High tech start-ups in University science park incubators: The relationship between the start-up's lifecycle progression and use of the incubator's resources. Technovation, 28, 277-290.

McAdam, M., Miller, K., \& McAdam, R. (2016). Situated regional university incubation: A multi-level stakeholder perspective. Technovation, 50-51, 69-78.

Mian, S. A. (1996). Assessing value-added contributions of university technology business incubators to tenant firms. Research Policy, 25, 325-335.

Mian, S. A., Lamine, W., \& Fayolle, A. (2016). Technology business incubation: An overview of the state of knowledge. Technovation, 50-51, 1-12.

North, D., Baldock, R., \& Ullah, F. (2013). Funding the growth of UK technology-based small firms since the financial crash: Are there breakages in the finance escalator? Journal of Venture Capital, 15, 237-260.

Oakey, R. P. (2003). Funding innovation and growth in UK new technology-based firms: Some observations on contributions from public and private sectors. Venture Capital, 5(2), 161-180.

OECD. (1997). Technology incubators: Nurturing small firms. OECD No. (97) 202: Issue Paris.

Pauwels, C., Clarysse, B., Wright, M., \& Van Hove, J. (2016). Understanding a new generation incubation model: The accelerator. Technovation, 50-51, 13-24.

Perez-Luno, A., Wilklund, J., \& Cabrera, R. V. (2011). The dual nature of innovation activity: How entrepreneurial orientation influences innovation generation and adoption. Journal of Business Venturing, 26, 555-571.

Phan, P. H., Siegel, D. S., \& Wright, M. (2005). Science parks and incubators: Observations, synthesis and future research. Journal of Business Venturing, 20, 165-182.

Ratinbo, T., \& Henriques, E. (2010). The role of science parks and business incubators in converging countries: Evidence from Portugal. Technovation, 30, 278-290.

Rothaermel, F., \& Thursby, M. (2005a). Incubator firm failure or graduation? The role of university linkages. Research Policy, 34, 1076-1090.

Rothaermel, F., \& Thursby, M. (2005b). University-incubator firm knowledge flows: Assessing their impact on incubator firm performance. Research Policy, 34, 305-324.

Sa, C., \& Lee, H. (2012). Science, business, and innovation: Understanding networks in technology-based incubators. $R \& D$ Management, 42, 243-253. 
Salvador, E. (2011). Are science parks and incubators good "brand names" for spin-offs?The case study of Turin. The Journal of Technology Transfer, 36, 203-232.

Schwartz, M. (2009). Beyond incubation: An analysis of firm survival and exit dynamics in the postgraduation period. Journal of Technology Transfer, 34, 403-421.

Schwartz, M. (2012). Incubator time, incubator age, and firm survival after graduation. International Journal Entrepreneurship and Innovation Management, 15, 108-130.

Shrader, R., \& Siegel, D. S. (2007). Assessing the relationship between human capital and firm performance: Evidence from technology-based new ventures. Entrepreneurship Theory and Practice, 31, 893-908.

Siegel, D. S., Westhead, P., \& Wright, M. (2003). Science parks and the performance of new technologybased firms: A review of recent U.K. evidence and an agenda for future research. Small Business Economics, 20, 177-184.

Siegel, D. S., Wright, M., \& Lockett, A. (2007). The rise of entrepreneurial activity at universities: Organizational and societal implications. Industrial and Corporate Change, 16, 489-504.

Smith, D. J., \& Zhang, M. (2012). Introduction: The evolution of the incubator concept. The International Journal of Entrepreneurship and Innovation, 13, 227-234.

Storey, D. J., \& Tether, B. S. (1998). New technology-based firms in the European Union: An introduction. Research Policy, 26, 933-946.

Wright, M., Birley, S., \& Mosey, S. (2004). The formation of high tech university spinout companies: The role of joint ventures and venture capital investors. Journal of Technology Transfer, 29, 287-310.

Wright, M., Clarysse, B., \& Lockett, A. (2008). Mid-range universities' linkages with industry: Knowledge types and the role of intermediaries. Research Policy, 37, 1205-1223.

Xiao, L., \& North, D. (2012). Institutional transition and the financing of high-tech SMEs in China: A longitudinal perspective. Venture Capital, 14, 1-19.

Xiao, L., \& North, D. (2013). Technology business incubators and the graduation performance of technology-based start-up firms: Regional evidence from China. Presented at Academy of Management Annual Meeting 2013 Orlando, USA.

Xiao, L., \& Ritchie, B. (2011). Informal investors, investing and networks in China: An exploratory study. Journal of Private Equity, 14, 72-85.

Zhang, H., \& Sonobe, T. (2011). Business incubators in China: An inquiry into the variables associated with incubate success. Economics, 5, 2011-2017. 